\title{
Impact of Organizational Justice and Psychological Empowerment on Perceived Organizational Performance: The Mediating Role of Organizational Citizenship Behaviour
}

\author{
Mirza Muhammad Azeem¹, Muhammad Abrar2, Mohsin Bashir ${ }^{*}$, Ali Zubair ${ }^{1}$ \\ ${ }^{1}$ Department of Business Administration, Government College University, Faisalabad, Pakistan \\ ${ }^{2}$ Department of Business Administration, National Textile University, Faisalabad, Pakistan \\ Email: ${ }^{\text {mohsinhust@gmail.com }}$
}

Received 11 April 2015; accepted 21 May 2015; published 25 May 2015

Copyright (C) 2015 by authors and Scientific Research Publishing Inc.

This work is licensed under the Creative Commons Attribution International License (CC BY).

http://creativecommons.org/licenses/by/4.0/

(c) (i) Open Access

\begin{abstract}
The present research analysed the relationships among organizational justice, psychological empowerment, organizational citizenship behaviour, and perceived organizational performance. For this purpose, the data was collected from 260 employees working in different banks in Pakistan. Baron and Kenny's regression approach was used to test the mediation effect. In addition, Sobel test by Preacher, K. J. \& Hayes, A. F. was also used for bootstrapping in the SPSS. All the alternate hypotheses of the study were accepted. The results of the study revealed that organizational citizenship behaviour partially mediated the relationship between organizational justice and perceived organizational performance. It was also found that organizational citizenship behaviour fully mediated the relationship between psychological empowerment and perceived organizational performance.
\end{abstract}

\section{Keywords}

Organizational Justice, Procedural Justice, Distributive Justice, Psychological Empowerment, Organizational Citizenship Behaviour, Perceived Organizational Performance.

\footnotetext{
${ }^{*}$ Corresponding author.
} 


\section{Introduction}

Organizations are constantly changing in every field of operations due to globalization. Working procedures of the organizations are also changing rapidly due to the advancements in technology. There are some active $\mathrm{Hu}-$ man Resource Management (HRM) practices that can be helpful in providing solutions to the problems which are the result of continuously changing of the work environment. These practices can be a major source of organizational success. It is not an easy task to manage the people of current age group at the same time in vibrant and rapidly changing environment at different work sites. There should be different treatments for different people because one dimension of benefits is preferred by some individuals and the others may prefer a different dimension of benefits. For this purpose, such HRM practices should be implemented that provide strength to the organization in form of increased performance of the employees [1].

Currently, the significance of managing firm's resources should be taken into mind for the success of any firm. Human resources play a vital part and must be considered [2]. Human resources are the key factors for differentiating success factor for many organizations especially for service industry. According to Shafie et al. [3], human resource provides goals and gives life to the organization. Additionally, the main challenges for many firms in these days are to recruit, hold, manage, and satisfy their employees who can help to increase the effectiveness of the firm.

A deep study of material in management research shows that the productive organizational performance is in direct relationship with the motivation level and commitment level of the employees in the organization. Motivation of employees at workplace is influenced and shaped by many factors. Some of the factors that influence and shape the motivation of employees are organizational justice and provision of basic needs for the employees. Organizational justice is achieved when people notice that they are treated at work equally and fairly. Well known psychologists also emphasize that in social exchange, fairness produces the motivation. Because everyone will get what they deserve if everything is fair in life. Individuals compare themselves with the actions of others to determine if they are treated fairly or not. Organizational justice can't be taken too lightly because it is a major source of motivation of the employees. The three main components of organizational justice that are discussed extensively in research are "distributive justice", "procedural justice", and "interactional justice". Procedural justice means that employees perceive in their minds that the decisions made by the management are transparent and fair while allocating the resources or resolving the disputes. Distributive justice is about the fair allocation of resources and rewards [4].

Most of the researchers and practitioners in the field of organizational theory find that psychological empowerment is very important construct and should be critically evaluated [5] [6]. After growing global competition and organizational change, it was required from the employee side that they should be motivated and able to take initiatives [7]. Due to this requirement, interest in psychological empowerment increases rapidly. Although the research on the construct is increasing and important, there are a few theoretically derived and tested measures of psychological empowerment. According to Zimmerman [8], psychological empowerment was not measured by the previous researchers by keeping work situations in mind which limited the usefulness of the construct in organizational research.

OCB is one of the critical and important topic in the research of organizational behaviours. In OCB, the employees perform duties beyond their obligations and cooperate voluntarily and consult with others [9]. It has been found that OCB helps in the long-term success of the organization [10]. OCB is recognized as a conscious and autonomous behaviour by Organ [11], which leads to organizational productivity.

In previous researches the effect of organizational justice and psychological empowerment was shown on organizational citizenship behaviour. But the mediating effect of organizational citizenship behaviour among organizational justice, psychological empowerment and perceived organizational performance was not tested. In previous research the impact of organizational justice and psychological empowerment was tested on organizational citizenship behaviour as dependent variable. In current study, we take organizational citizenship behaviour as mediating variable and test its mediating effect between organizational justice, psychological empowerment and perceived organizational performance.

\section{Literature Review}

Organizational Justice: According to Colquitt et al. [12], in managerial and psychological researches, a very large amount of attention is given to organizational justice. Organizational justice means that staff perceive that 
organizational behaviours are fair [13]. Based on previous research by different researchers and scholars, it has been found that there are three forms of organizational justice: distributive, procedural, and interactional justice [14] [15]. Distributive justice is a term that tells about the perceived justice from the consequences people receive as described by Mcdowal \& Fletcher. Procedural justice is all about the perception of people about the procedures to which the consequences belong (Mcdowal \& Fletcher, 2004). Bies \& Moag [16] suggested interactional justice as the quality of interpersonal interactions of organizational decision-makers during organizational procedures. Interacting with one another, these three dimensions of justice form the perceived justice for the people in the workplace [17].

According to the theory of justice, the information of distributive, procedural, and interactional justice is processed for making and revising total justice judgments. According to this theory, some other attitudes like job satisfaction [18] [19], OCB [20], organizational commitment [21] [22], organizational trust [23]-[25], and aggressive behaviours [26] are also effected with organizational justice. According to Herrenkohl et al. [27], perceived justice is an important factor to differentiate more empowered (psychologically) and less empowered groups.

Greenberg [28] explains in an article in which previous as well as current and future of organizational justice is discussed that many variables related to organizational behaviour outcome may be potentially explained by the research on organizational justice. Organizational justice is a conceptual word used in literature to explain the contribution of fairness because it is in direct relationship to the workplace. Most importantly, organizational justice is all about the ways in which employees feel that either they are treated fairly or not in their jobs in the organization. It is also considered by the employees that how these determinations affect other variables which are related to work. According to Alsalem \& Alhaiani [29], organizational justice can help in explaining the matter that why the workers react against unfair results or unsuitable procedures and inter-connections.

After considering the above discussed points, the following hypothesis can be considered;

H1: Organizational iustice has positive effect on perceived organizational performance.

Psychological Empowerment: There are similar definitions about the psychological empowerment which are presented by different researchers. In the early research, the researchers on organizational research give more attention to empowering as a delegation of power and authority from higher level of management to lower level of management. They also increase the access of lower staff to the knowledge and resources of the organization [30] [31]. But in the recent research, the researchers like Thomas and Velthouse (1990) supported the concept that this construct of psychological empowerment should be viewed from a different point of perception. Conger and Kanungo [32] on the other hand also claim that these management practices of delegation of authority are one side of those practices that empower employees but it is not a pet condition. Until recently, little research has taken an individual perspective on empowerment, focusing on the psychological experience of empowerment.

A detailed definition of empowerment hasn't been offered yet although the concept has been discussed and used in literature for different studies. Mondros \& Wilson [33] believe that this concept is rarely identified and has been literally regarded. The reason for that is the absence of a historical and experimental context for this concept among other organizational concepts.

Empowerment means to give authority to others. Empowerment should be regarded from the view of a redistribution model by which power balance is provided through trust and cooperation protection [34]. Conger \& Kanungo (1988) focused on authority as the focal point of empowerment, giving discretion to the staff to make and exert their own decisions. Liu et al. [35] define empowerment as the mental relations of the employers and the employees. It is proved that psychological empowerment is correlated with organizational attitudes and behaviours [36].

The above discussion of different concepts about the psychological empowerment shows that it is a very important phenomenon in the field of social sciences and should be addressed deeply. Because individuals who are empowered are more loyal and sincere to the organization and positively contribute towards the improvements of the organizational performance. The above discussion can be used to pose the following hypothesis;

H2: Psychological empowerment has positive effect on perceived organizational performance.

Organizational Citizenship Behaviour: A long period of time ago, Dennis Organ and his associates Bateman [37] used the term "Organizational Citizenship Behaviour" (OCB) for first time in management research. According to the concept discussed by Barnard [38] in his research, OCB means "the willingness to cooperate" and Katz [39] [40] defined the same concept as "innovative and spontaneous behaviours". Organ (1988) defined the concept of organizational citizenship behaviours as "individual behaviour that is discretionary, not directly or 
explicitly recognized by the formal reward system, and that in the aggregate promotes the effective functioning of the organization. By discretionary, we mean that the behaviour is not an enforceable requirement of the role or the job description, that is, the clearly specifiable terms of the person's employment contract with the organization; the behaviour is rather a matter of personal choice, such that its omission is not generally understood as punishable”.

Advancement in organizational citizenship behaviour theory and research produced acceptable results for researchers. On the other hand unfortunate consequences have also been produced. For example, according to Van Dyne et al. [41], key focus of investigation on organizational citizenship behaviour and other interconnected concepts are on substantive validity defined by Schwab [42] rather than construct validity. After Schwab (1980), Van Dyne et al. (1995) recommended that if special attention did not given to the theoretical explanations of the concept, then there is a danger of development of such literature which will be of no value in the future. It is because the researchers have focused much on relationship between organizational citizenship behaviour and other variables instead of presenting a more clear definition of organizational citizenship behaviour.

Taken together, the overall results reported in previous research provides general support for the hypothesis that organizational citizenship behaviours are related to organizational effectiveness. So it is to be said that organizational citizenship behaviour is a construct that should be considered carefully in the research environments and it is a very important factor that contributes to the increment of the individual's motivation towards the organization. Therefore, it is reported to be such variable that can increase the performance of the firm as the satisfied employees will be more productive as compared to those who are not satisfied. On the basis of above literature, the followings hypotheses are as follows;

H3: Organizational justice leads to perceived organizational performance through the mediating effects of OCB.

H4: Psychological empowerment leads to perceived organizational performance through the mediating effects of OCB.

Perceived Organizational Performance: After surfing a lot of research literature it was found that organizational performance had been measured through various indicators. Delany \& Huselid [43] used perceptual measures of organizational performance, profitability ratios and liquidity ratios were used by Terpstra \& Rozell [44] to measure the financial performance of firm, sales based or value added in the products of the organization by each employee were practiced by Black \& Lynch [45] and Cappelli \& Neumark [46] and productivity was measured in physical form were used by Arthur [47]. Singh [48] has discovered in his studies that there is a drawback of this approach because it is highly subjective for the individual to find the improvements in the organization in which the individual is working as well as the performance of individual himself, and collecting about the performance of a rival firm. It was therefore required by the HRM managers that they should make standard to test the performance of their own firm with the performance of preceding years to determine the perceived performance of firm and the performance of the individual at the same time.

Present theoretical efforts on resource-based observation of the firm support the concept that suitable human resource practices may be a substantial base of "competitive advantage" and claim that all the valuable and productive organizational resources lead to sustainable competitive advantage. Resource-based theory says that these foundations of value are progressively available to almost everyone somewhere and they are easy to duplicate, mainly when paralleled to complex social arrangements like human resource systems. Good human resource management practices has an effect on "organizational performance" by improving the "attitude of employees, skills, abilities, knowledge, motivation and working patterns”, according to Delaney \& Huselid (1996).

Several writers in the research field have discovered that there are relations among the HRM practices of the individuals' and performance of the firm in the market. As described by Youndt et al. [49], the human resource practices were in direct relationship with the all dimensions of market performance of the firm. Perceived organizational performance is measured by the perception of the employees about the performance of their firm as compared to the financial position of the firm in previous years. Employees also compare their firm with the competitors to measure the improvements. On the basis of above discussion the research framework is shown in Figure 1 for current study.

\section{Methodology}

This study was conducted to provide evidence about the effects of organizational justice and psychological em- 


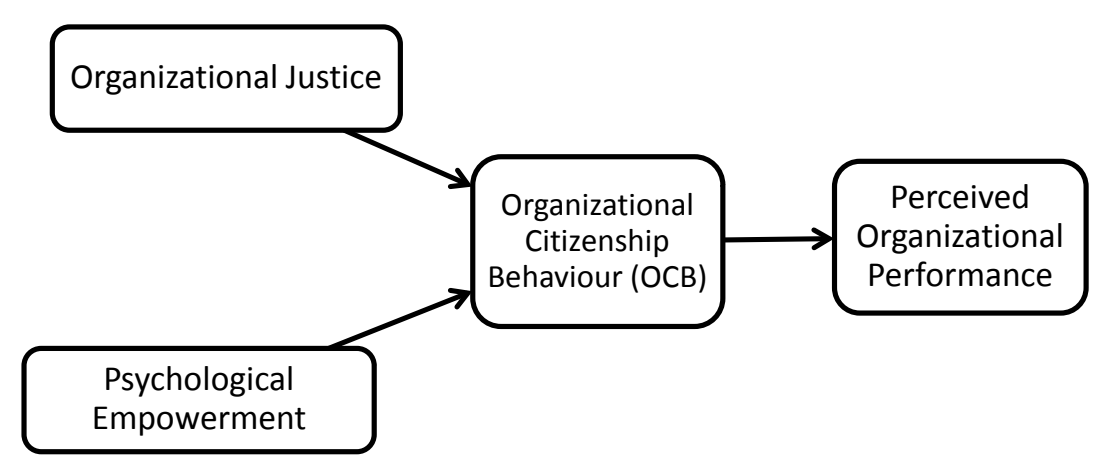

Figure 1. Conceptual framework.

powerment on perceived organizational performance and to test the mediating effect of organizational citizenship behaviour among them. Quantitative approach is used in this study and a questionnaire based on two sections in which first section was about the demographics and second section was about the questions related to the variables. For the purpose of this study, 300 questionnaires were distributed and 260 were returned by the respondents. It is a general consideration that characteristics of population are represented by the sample chosen from that population.

Close ended questionnaire based on five point Likert scale with options from strongly agree to strongly disagree. Each option was assigned a scale. $5=$ strongly agree, $4=$ agree, $3=$ indifferent/neutral, $2=$ disagree and 1 = strongly disagree.

To measure the dependent variable (Perceived Organizational Performance) questionnaire was based on questions/items used by Singh (2004), Qureshi et al. [50] and Maqsood (2010). They used ten items to measure organizational performance (e.g. Quality of our products/services has been improved). Two dimensions of organizational justice i.e. procedural justice and distributive justice were measured by using the questionnaire of Niehoff \& Moorman (1993) with 11 items (e.g. my work schedule is fair). To measure psychological empowerment, the questionnaire of Spreitzer [51] with 11 items was used (e.g. the work I do is very important to me). To measure OCB, the questionnaire of Podsakoff et al. [52] examining 22 items (e.g. Helps others who have heavy workloads) with 5-point Likert scale (from 1-strongly disagree to 5-strongly agree) was used. Cronbach Alpha for organizational justice, psychological empowerment, organizational citizenship behaviour, and perceived organizational performance was $0.68,0.80,0.81$, and 0.72 respectively.

\section{Findings and Analysis}

\subsection{Data Analysis Tools and Techniques}

Regression analysis of Baron and Kenny [53] and Sobel macro by Preacher and Hayes [54] were used to test and cross verification of the hypothesis of the study. Pearson correlation was used to check the strength of relationship among the variables of study.

\subsection{Profile of Respondents}

Out of 300 questionnaires distributed, 260 were returned completed showing $86.67 \%$ response rate. According to Table 1 there were $81.9 \%$ male respondents and remaining $18.1 \%$ were female respondents. There were $17.7 \%$ respondents in group "less than 30 (years old)". The majority of the respondents were from 30 to 35 years old representing $60.4 \%$. While number of respondents in all remaining age groups was less than $10 \%$. Married were $64.6 \%$ and regular were $79.6 \%$. Most of the respondents have experience from 3 to 5 years and represent 34.2\% and remaining "less than three years", "6 to 10 years", "11 to 15 years", "16 to 20 years" and "more than 21 years" of experience represent $20.8 \%, 27.7 \%, 5.8 \%, 7.3 \%$, and $4.2 \%$ in the same order.

Table 2 shows the matrix of Pearson Correlation, Mean and Standard Deviations and it is clear from the observation of the matrix that there is significant relationship between the variables of the current study i.e. dependent variable (perceived organizational performance), independent variables (organizational justice, psychological empowerment) and intervening variable (organizational citizenship behaviour). Table 2 shows that there is positive relationship between all the variables. It means that with the increase in one variable the 
Table 1. Demographics of the respondents.

\begin{tabular}{|c|c|c|}
\hline Demographics & Number of Participants (N) & Percentage \\
\hline \multicolumn{3}{|l|}{ Gender } \\
\hline Male & 213 & 81.9 \\
\hline Female & 47 & 18.1 \\
\hline \multicolumn{3}{|l|}{ Age } \\
\hline Less than 30 & 46 & 17.7 \\
\hline 30 to 35 & 157 & 60.4 \\
\hline 36 to 40 & 18 & 6.9 \\
\hline 41 to 45 & 16 & 6.2 \\
\hline 46 to 50 & 16 & 6.2 \\
\hline 51 and Above & 7 & 2.7 \\
\hline \multicolumn{3}{|l|}{ Marital Status } \\
\hline Unmarried & 92 & 35.4 \\
\hline Married & 168 & 64.6 \\
\hline \multicolumn{3}{|l|}{ Experience } \\
\hline Less than 3 years & 54 & 20.8 \\
\hline 3 to 5 years & 89 & 34.2 \\
\hline 6 to 10 years & 72 & 27.7 \\
\hline 11 to 15 years & 15 & 5.8 \\
\hline 16 to 20 years & 19 & 7.3 \\
\hline 21 and above & 11 & 4.2 \\
\hline \multicolumn{3}{|l|}{ Nature of Job } \\
\hline Contract & 53 & 20.4 \\
\hline Regular & 207 & 79.6 \\
\hline
\end{tabular}

Table 2. Pearson correlation results.

\begin{tabular}{|c|c|c|c|c|c|c|}
\hline & Mean & SD & OJ & PE & ОСВ & POP \\
\hline OJ & 3.43 & 0.46 & 1 & & & \\
\hline $\mathrm{PE}$ & 3.66 & 0.53 & $0.51^{* *}$ & 1 & & \\
\hline ОСВ & 3.87 & 0.34 & $0.40^{* *}$ & $0.72^{* *}$ & 1 & \\
\hline POP & 4.06 & 0.38 & $0.52^{* *}$ & $0.53^{* *}$ & $0.73^{* *}$ & 1 \\
\hline
\end{tabular}

${ }^{* *}$ Correlation is significant at the 0.01 level (2-tailed).

result will be increase in the other variable. In simple words we can say that increase in dependent variable also increase the value of dependent variable. All the values of correlation are significant at 0.012 -tailed test. Independent variables (organizational justice, psychological empowerment) are positively correlated with mediating variable (organizational citizenship behaviour); it is also found that mediating variable is also positively correlated with dependent variable (perceived organizational performance).

Table 3 below shows the results of regression analysis. The result shows that there is a significant positive relationship between all the variables of study (organizational justice, psychological empowerment, organizational citizenship behaviour, and perceived organizational performance). $\mathrm{R}^{2}$ shows that how much variation in dependent variable is explained by independent variable. In our case the highest value of $\mathrm{R}^{2}=0.53$ which is 
Table 3. Regression analysis results between the variables of study.

\begin{tabular}{ccccc}
\hline & $\boldsymbol{\beta}$ & $\mathbf{R}^{2}$ & $\Delta \mathbf{R}^{2}$ & Sig \\
\hline OJ $\rightarrow$ POP & 0.43 & 0.27 & 0.27 & 0.00 \\
OJ $\rightarrow$ OCB & 0.29 & 0.16 & 0.15 & 0.00 \\
OCB $\rightarrow$ POP & 0.83 & 0.53 & 0.53 & 0.00 \\
OJ $\rightarrow$ OCB $\rightarrow$ POP & 0.23 & 0.60 & 0.59 & 0.00 \\
PE $\rightarrow$ POP & 0.39 & 0.29 & 0.28 & 0.00 \\
PE $\rightarrow$ OCB & 0.45 & 0.51 & 0.51 & 0.00 \\
PE $\rightarrow$ OCB $\rightarrow$ POP & 0.02 & 0.53 & 0.53 & 0.66
\end{tabular}

between organizational citizenship behaviour and perceived organizational performance. OCB partially mediates between OJ and POP because the results remain significant after entering the mediator in analysis. On the other hand, OCB fully mediates the relationship between PE and POP because the results become insignificant after including the mediator in the analysis.

\subsection{Limitations and Suggestions for Future Research}

While conducting the research there were many limitations in it. First one is the limitation of sample size. For more accurate results a large enough sample should be considered. Second, there is lack of understanding in the respondents about the concepts asked in the questions. Thirdly, organizational performance was measured according to the perception of employees which may show biased results and far from reality.

This study was conducted in a developing country where the organizations were not fully adopting the management policies and practices discussed in literature. There is a lot of attention required in the future to test such concepts in other fields of industry. The current study was in banking sector. Other sectors like services and manufacturing should also be included in future research.

\section{References}

[1] Maqsood, T. (2010) Impact of Human Resource Management (HRM) Practices on Organizational Performance: A Mediating Role of Employee Performance. PhD Thesis, Muhammad Ali Jinnah University, Islamabad.

[2] Nadiri, H. and Tanova, C. (2010) An Investigation of the Role of Justice in Turnover Intentions, Job Satisfaction, and Organizational Citizenship Behaviour in Hospitality Industry. International Journal of Hospitality Management, 29, 33-41. http://dx.doi.org/10.1016/j.ijhm.2009.05.001

[3] Shafie, B., Baghersalimi, S. and Barghi, V. (2013) The Relationship between Leadership Style and Employee Performance. Singaporean Journal of Business Economics and Management Studies, 2, 21-29.

[4] Kreitner, R. and Kinicki, A. (2002) Organizational Behaviour. 2nd Edition, Mcgraw Hill, London, 206-220.

[5] Kanter, R.M. (1989) The New Managerial Work. Harvard Business Review, 66, 85-92.

[6] Thomas, K.W. and Velthouse, B.A. (1990) Cognitive Elements of Empowerment. Academy of Management Review, 15, 666-681.

[7] Drucker, P.F. (1988) The Coming of the New Organization. Harvard Business Review, 66, 45-53.

[8] Zimmerman, M.A. (In Press) The Measurement of Psychological Empowerment. American Journal of Community Psychology.

[9] Organ, D.W., Podsakoff, P.M. and MacKenzie, S.B. (2006) Organizational Citizenship Behaviour: Its Nature, Antecedents, and Consequences. Sage, Thousand Oaks.

[10] Castro, C.B., Armario, E.M. and Ruiz, D.M. (2004) The Influence of Employee Organizational Citizenship Behavior on Customer Loyalty. International Journal of Service Industry Management, 15, 27-53. http://dx.doi.org/10.1108/09564230410523321

[11] Organ, D.W. (1988) Organizational Citizenship Behaviour: The Good Soldier Syndrome. Lexington Books, Lexington.

[12] Colquitt, J.A., Conlon, D.E., Wesson, M.J., Porter, C.O.L.H., and Ng, K.Y. (2001) Justice at the Millennium: A Mete Analytic Review of 25 Years of Organizational Justice Research. Journal of Applied Psychology, 83, 425-445.

http://dx.doi.org/10.1037/0021-9010.86.3.425 
[13] Campbell, L. and Finch, E. (2004) Customer Satisfaction and Organizational Justice. Facilities, 22, 178-189. http://dx.doi.org/10.1108/02632770410547543

[14] Mcdowall, A. and Fletcher, C. (2004) Employee Development: An Organizational Justice Perspective. Personnel Review, 33, 7-15. http://dx.doi.org/10.1108/00483480410510606

[15] Yang, J., Mossholder, K.W. and Peng, T.K. (2009) Supervisory Procedural Justice Effects: The Mediating Roles of Cognitive and Affective Trust. The Leadership Quarterly, 20, 143-154. http://dx.doi.org/10.1016/j.leaqua.2009.01.009

[16] Bies, R.J. and Moag, J.F. (1986) Interactional Justice: Communication Criteria of Fairness. In: Lewicki, R.J., Sheppard, B.H. and Bazerman, M.H., Eds., Research on Negotiations in Organizations, Vol. 1, JAI Press, Greenwich, 43-55.

[17] Kim, T.Y. and Leung, K. (2007) Forming and Reacting to Overall Fairness: A Cross-Cultural Comparison. Organizational Behaviour and Human Decision Processes, 104, 83-95. http://dx.doi.org/10.1016/j.obhdp.2007.01.004

[18] Kim, S. (2002) Participative Management and Job Satisfaction: Lessons for Management Leadership. Public Administration Review, 62, 231-241. http://dx.doi.org/10.1111/0033-3352.00173

[19] Loi, R., Yang, J.X. and Diefendorff, J.M. (2009) Four-Factor Justice and Daily Job Satisfaction: A Multi-Level Investigation. Journal of Applied Psychology, 94, 770-781. http://dx.doi.org/10.1037/a0015714

[20] Karriker, J.H. and Williams, M.L. (2009) Organizational Justice and Organizational Citizenship Behaviour: A Mediated Multifoci Model. Journal of Management, 35, 112-135. http://dx.doi.org/10.1177/0149206307309265

[21] Chughtai, A.A. and Zefar, S. (2006) Antecedents and Consequences of Organizational Commitment among Pakistani University Teachers. Applied H.R.M. Research, 11, 39-64.

[22] Moorman, R.H., Niehoff, B.P. and Organ, D.W. (1993) Treating Employees Fairly and Organizational Citizenship Behaviour: Sorting the Effects of Job Satisfaction, Organizational Commitment, and Procedural Justice. Employee Responsibilities and Rights Journal, 6, 209-225. http://dx.doi.org/10.1007/BF01419445

[23] Davis, D.D. and Bryant, J.L. (2010) Leader-Member Exchange, Trust, and Performance in National Science Foundation Industry/University Cooperative Research Centers. Journal of Technology Transfer, 35, 511-526. http://dx.doi.org/10.1007/s10961-009-9144-0

[24] Diploma, M. and Guy, S. (2009) The Impact of Organizational Justice on Climate and Trust in High Schools. Journal of School Leadership, 19, 382-405.

[25] Hoy, W. and Tarter, C. (2005) Organizational Justice in School: No Justice without Trust. Human Resources Abstract, 18, 250-259.

[26] Jawahar, I.M. (2002) A Model of Organizational Justice and Workplace Aggression. Journal of Management, 28, 811834. http://dx.doi.org/10.1177/014920630202800606

[27] Herrenkohl, L.R., Palincsar, A.S., DeWater, L.S. and Kawasaki, K. (1999) Developing Scientific Communities in Classrooms: A Socio-Cognitive Approach. Journal of the Learning Sciences, 8, 451-493. http://dx.doi.org/10.1080/10508406.1999.9672076

[28] Greenberg, J. (1990) Looking Fair Being Fair: Managing Impressions of Organizational Justice. Research in Organizational Behaviour, 12, 57-111.

[29] Alsalem, M. and Alhaiani, A. (2007) Relationship between Organizational Justice and Employees Performance. Aledari, 108, 97-110.

[30] Mainiero, L.A. (1986) Coping with Powerlessness: The Relationship of Gender and Job Dependency to Empowerment-Strategy Usage. Administrative Science Quarterly, 31, 633-653. http://dx.doi.org/10.2307/2392967

[31] Neilsen, E.H. (1986) Empowerment Strategies: Balancing Authority and Responsibility. In: Srivastva, S. and Associates, Eds., Executive Power, Jossey-Bass, San Francisco, 78-110.

[32] Conger, J.A. and Kanungo, R.N. (1988) The Empowerment Process: Integrating Theory and Practice. Academy of Management Review, 13, 471-482.

[33] Mondros, J.B. and Wilson, S.M. (1994) Organizing for Power and Empowerment. Columbia University Press, New York.

[34] Karen, L. (1995) Human Resource Management Rhetorics and Realities. Macmillan Press, Basingstoke, 385.

[35] Liu, A.M.M., Chiu, W.M. and Fellows, R. (2007) Enhancing Commitment through Work Empowerment. Engineering, Construction and Architectural Management, 14, 568-580. http://dx.doi.org/10.1108/09699980710829021

[36] Laschinger, H.K.S. and Finegan, J. (2005) Using Empowerment to Build Trust and Respect in the Workplace: A Strategy for Addressing the Nursing Shortage. Nursing economics, 23, 6-13.

[37] Bateman, T.S. and Organ, D.W. (1983) Job Satisfaction and the Good Soldier: The Relationship between Affect and Employee “Citizenship”. Academy of Management Journal, 26, 587-595. http://dx.doi.org/10.2307/255908

[38] Barnard, C.I. (1938) The Functions of the Executive. Harvard University Press, Cambridge. 
[39] Katz, D. (1964) Motivational Basis of Organizational Behaviour. Behavioural Science, 9, 131-146. http://dx.doi.org/10.1002/bs.3830090206

[40] Katz, D. and Kahn, R.L. (1966) The Social Psychology of Organizations. Wiley, New York.

[41] Van Dyne, L., Cummings, L.L. and McLean Parks, J. (1995) Extra-Role Behaviours: In Pursuit of Construct and Definition Clarity. In: Cummings, L.L. and Staw, B.M., Eds., Research in Organizational Behaviour, Vol. 17, JAI Press, Greenwich, 215-285.

[42] Schwab, D.P. (1980) Construct Validity in Organizational Behaviour. In: Cummings, L.L. and Staw, B.M., Eds., Research in Organizational Behaviour, Vol. 2, JAI Press, Greenwich, 3-43.

[43] Delaney, J.T. and Huselid, M.A. (1996) The Impact of Human Resource Management Practices on Performance in For-Profit and Non-Profit Organizations. Academy of Management Journal, 39, 949-969. http://dx.doi.org/10.2307/256718

[44] Terpstra, D.E. and Rozell, E.J. (1993) The Relationship of Staffing Practices to Organizational Level Measures of Performance. Personnel Psychology, 46, 27-48. http://dx.doi.org/10.1111/j.1744-6570.1993.tb00866.x

[45] Black, S.E. and Lynch, L.M. (2001) How to Compete: The Impact of Workplace Practices and Information Technology on Productivity. Review of Economics and Statistics, 83, 434-445. http://dx.doi.org/10.1162/00346530152480081

[46] Cappelli, P. and Newmark, D. (2001) Do "High Performance” Work Practices Improve Establishment Level Outcome? Industrial and Labour Relations Review, 54, 737-775. http://dx.doi.org/10.2307/2696111

[47] Arthur, J.B. (1994) Effects of Human Resources Systems on Manufacturing Performance and Turnover. Academy of Management Journal, 37, 670-87. http://dx.doi.org/10.2307/256705

[48] Singh, K. (2004) Impact of HR Practices on Perceived Firm Performance in India. Asia Pacific Journal of Human Resources, 42, 301-317. http://dx.doi.org/10.1177/1038411104048170

[49] Youndt, M., Snell, S., Dean Jr., J. and Lepak, D. (1996) Human Resource Management, Manufacturing Strategy, and Firm Performance. Academy of Management Journal, 39, 836-866. http://dx.doi.org/10.2307/256714

[50] Qureshi, M.T., Mohammad, R.I. and Syed, H.T. (2007) Impact of Human Resource Management Practices on Organizational Performance in Pakistan. Journal of Business \& Policy Research, 3, 128-138.

[51] Spreitzer, G.M. (1995) Psychological Empowerment in the Workplace: Dimensions, Measurement, and Validation. Academy of Management Journal, 38, 1442-1465. http://dx.doi.org/10.2307/256865

[52] Podsakoff, P.M., MacKenzie, S.B., Moorman, R.H. and Fetter, R. (1990) Transformational Leader Behaviours and Their Effects on Followers' Trust in Leader, Satisfaction, and Organizational Citizenship Behaviours. The Leadership Quarterly, 1, 107-142. http://dx.doi.org/10.1016/1048-9843(90)90009-7

[53] Baron, R.M. and Kenny, D.A. (1986) Moderator-Mediator Variables Distinction in Social Psychological Research: Conceptual, Strategic, and Statistical Considerations. Journal of Personality and Social Psychology, 51, 1173-1182. http://dx.doi.org/10.1037/0022-3514.51.6.1173

[54] Preacher, K.J. and Hayes, A.F. (2004) SPSS and SAS Procedures for Estimating Indirect Effects in Simple Mediation Models. Behaviour Research Methods, Instruments, and Computers, 36, 717-731. http://dx.doi.org/10.3758/BF03206553 